\title{
Abundance and distribution of ophiuroids off Helgoland, German Bight (North Sea)*
}

\author{
K. Boos \& H.-D. Franke \\ Biologische Anstalt Helgoland, Alfred Wegener Institute for Polar and Marine Research, Helgoland, Germany
}

Ophiuroids are thought to significantly influence benthic communities by means of bioturbation, processing of organic matter, and as links in local food chains. This is mainly due to their abundance, feeding behaviour and high activity levels (Summers \& Nybakken 2000). Apart from various factors influencing their occurrence, such as hydro dynamics, depth and temperature, the sediment structure in particular determines the spatial distribution of the species, reflecting their lifestyle and feeding behaviour.

Therefore, the objective of the present study is to give an overview of the species diversity of ophiuroids off Helgoland, and to investigate whether the local species show a preference towards a specific substratum and how this preference affects their spatial distribution.

In total, 24 sediment samples (Van Veen grab, $0.1 \mathrm{~m}^{2}$ ) and additional dredge samples were taken at eight stations with different sediment types in the vicinity of the island of Helgoland (Fig. 1). The samples were examined for ophiuroids and grain size of sediment. Only adult specimens were considered and identified to the species level.

Six of nine species, which were previously recorded for the German Bight (Gerdes 1977) were confirmed in this study (Table 1). All ophiuroids classified as "common" as well as Acrocnida brachiata, which was graded as "rare" by Gerdes (1977), were found. The absence of Amphiura chiajei, Ophiura affinis and Ophiura sarsi in our samples, confirms these species' scarce occurrence in the German Bight as noted by Gerdes (1977).

The epibenthic Ophiura albida was highly abundant on all types of sediment. Ophiura albida maintains a variety of feeding mechanisms such as predation on benthic prey, as well as carrion and deposit feeding (Jangoux \& Lawrence 1982). This makes the animal rather unselective towards specific substrata.

Other species showed preferences towards certain substrata. In this regard, Ophiura ophiura was found, in low numbers, only on muddy substrata. Our results are in agreement with Ursin (1960). Earlier investigations

\footnotetext{
* Submitted as an extended abstract
}

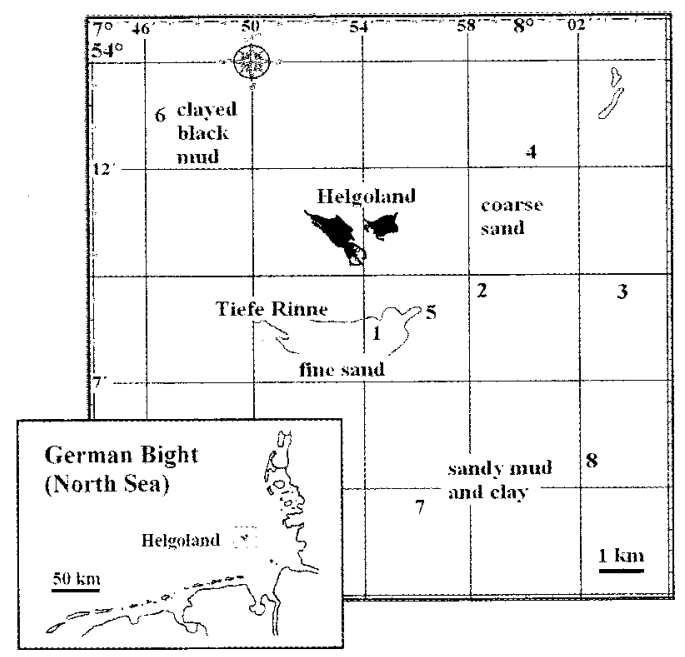

Figure 1. Sampling stations (1-8) around Helgoland, German Bight (North Sea).

prior to 1930 revealed high abundances of Ophizma ophiura on all types of substrate, but since then the species probably became rare and concentrated on muddy areas (Ursin 1960). Suggested dependence on the distribution of Sagitta species as food supply seems unlikely concerning the broad and unselective feeding behaviour of Ophiura ophiura (Feder 1981).

The fairly high rates of occurrence of Amphiura filiformis on muddy sediments refer to its infaunal lifestyle. Summers and Nybakken (2000) point out that, due to its increased grain surface, fine sediment contains more organic matter and has higher microbial activity than coarse substrata. Accordingly, fine sediment is more suitable for a burrowing life style.

The "rareness" of Acrocnida brachiata in the North Sea might be due to a temperature limitation (Ursin 1960). Considering its infaunal lifestyle, the low numbers of findings here suggest a preference towards fine sandy or clayed mud. Apart from deposit feeding, suspension feeding seems more obvious for Acrocnida brachiata. Hence, Ursin (1960) suggested 
Table 1. Sediment structure and abundance of ophiuroids in grab samples and dredge samples (in brackets).

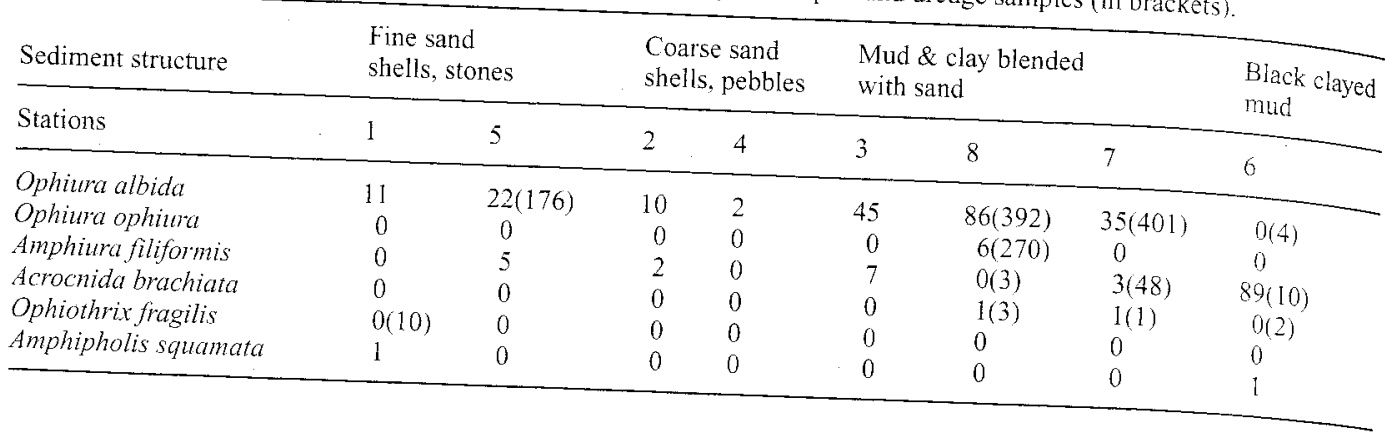

a correlation between the distribution of planktonic communities and the occurrence of Acrocnida brachiata.

Ophiothrix fragilis is known to be very common and highly abundant in the central North Sea. Although partly found on soft bottom, it is mostly found attached to shells, large stones or sponges depending on currents which supply planktonic food (Mortensen 1927). The only suitable substratum around Helgoland is present in the Tiefe Rinne (Fig. 1) were we found 10 individuals.

According to its preferred habitat, which is mainly in the littoral zone under stones and boulders (Ursin 1960), occurrences of Amphipholis squamata in the grab samples were rare. Additionally, scarceness in dredging could be due to the size of the animal being
smaller than the mesh size.

In conclusion, the spatial distribution of the ophiuroids seems to be affected by sediment structure and additionally, by the species' feeding behaviour which determines the animals lifestyle. Ophiuroids (e.g. Ophiura albida) maintaining different modes of feeding, seem to be more randomly spread on different substrata than those being specialized in feeding behaviour.

In order to get more detailed information on distributional patterns and their causes, further field and laboratory investigations are required.

\section{ACKNOWLEDGEMENTS}

Many thanks to Reinhard Saborowski, Lars Gutow and Reinhold Müller for helping with the manuscript and the work on the presentation. Thanks to the crew of the RV "Uthörn" and the Alfred-Wegener Institute for Polar and Marine Research for financial support.

\section{REFERENCES}

Feder, H.M. 1981. Aspects of the feeding biology of the brittlestar Ophiura texturata. Ophelia 20(2): 215-235.

Gerdes, D. 1977. Zur Verteilung der Echinodermen in de Deutschen Bucht. Diplomarbeit, Universität Kiel.

Jangoux, M. \& Lawrence, J.M. (eds.) 1982. Echinoderm nutrition. Rotterdam: Balkema

Mortensen, Th. 1927. Handbook of the echinoderms of the British Isles. London: Humphrey Milford Oxford University Press.

Summers, A.C. \& Nybakken, J. 2000. Brittle star distribution patterns and population densities on the continental slope off central California (Echinodermata: Ophiuroidea). Deep-Sea Research II 47: 1107-1137.

Ursin, E. 1960. A quantitative investigation of the echinoderm fauna of the central north sea. Meddeleleser Fra Danmarks Fisker - Og Havindersogelser, Ny Serie, Bind II, Nr. 24. 